\title{
Study of Prespa Lake's hydrology using isotopes and other relevant techniques
}

\author{
T. Anovski ${ }^{1}$, V. Popov ${ }^{2}$, S. Amataj ${ }^{3}$, E. Anovska-Jovcheva ${ }^{1}$, \\ Z. Jovchev ${ }^{4}$, I. Stojmenovska ${ }^{1}$, K. Anovski ${ }^{1} \&$ J. Milevski ${ }^{5}$ \\ ${ }^{1}$ Faculty of Technology and Metallurgy, \\ University of Sts Cyril \& Methodius, Skopje, Republic of Macedonia \\ ${ }^{2}$ Wessex Institute of Technology, Southampton, UK \\ ${ }^{3}$ Institute of Nuclear Physics, Tirana, Albania \\ ${ }^{4}$ Faculty of Electrical Engineering and Information Technology, \\ University of Sts Cyril \& Methodius, Skopje, Republic of Macedonia \\ ${ }^{5}$ National Hydrometeorological Service, Skopje, Republic of Macedonia
}

\begin{abstract}
On the borders between FYR of Macedonia, Albania and Greece there are three lakes: Ohrid Lake, and Big and Small Prespa Lakes. Galichica and Dry mountains separate the lakes. Several Projects (Supported by IAEA, NATO, EU, UNESCO and others) have been dealing with the determination of the water balance and the protection of Prespa and Ohrid Lakes with special attention to the explanation of the decreasing of the Prespa Lake water level, in excess of $8 \mathrm{~m}$ in the last decades. Investigations using Environmental isotopes and artificial tracers showed that Prespa Lake's waters drain through the Galichica and Dry mountains into Ohrid Lake. By using an appropriate model, relevant hydrogeological, hydro meteorological data, satellite images and a computer program which implements an adequate recursive and exponential equations, the volume of the underground aquifer below Galichica Mountain and the volume of the Prespa Lake have been calculated.
\end{abstract}

Keywords: environmental isotopes, lake's watershed, tracer experiments, mean residence time. 


\section{Introduction}

On the South-Eastern part of the FYR of Macedonia there are three lakes shown in Figure 1: Ohrid Lake, shared between Albania and FYR of Macedonia and the Big and Small Prespa Lakes, shared between the three neighbouring countries. Galichica and Dry mountains separate the lakes. According to an existing hypothesis by Cvijic [1], water from the Prespa Lake, which is shared by the three neighbouring countries, is drained through Galichica and Dry Mountains into Ohrid Lake. Field research conducted first by Anovski and collaborators [2] and later by other scientists [3-5], confirmed this hypothesis.

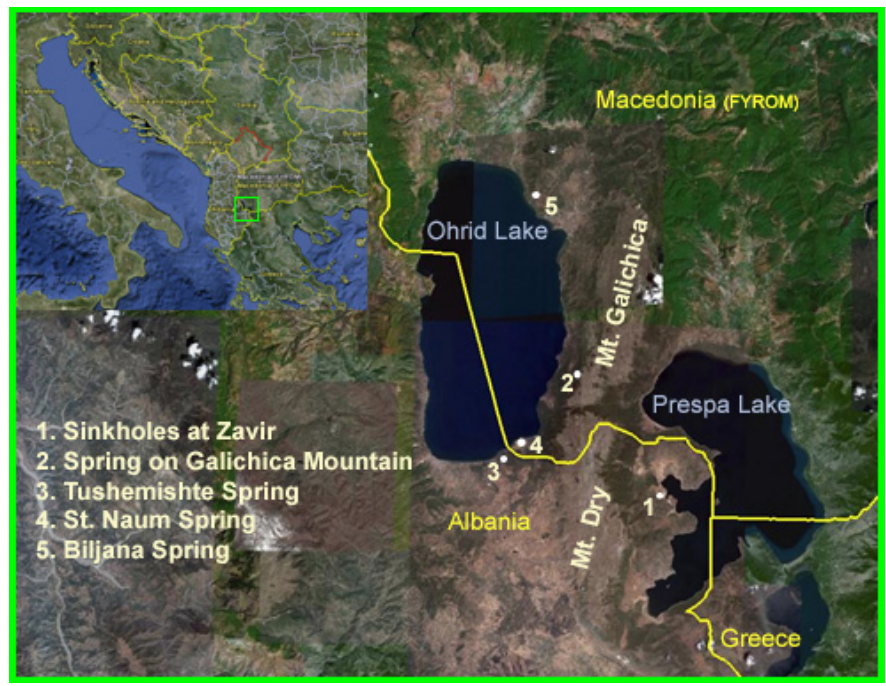

Figure 1: Investigated area of interest (courtesy of Google maps).

The Lakes Big Prespa $\left(253.6 \mathrm{~km}^{2}\right)$ and Small Prespa $\left(47.4 \mathrm{~km}^{2}\right)$ are at a referent level of 847,68 and $850 \mathrm{~m}$ above sea level (asl), respectively, and are linked by a small channel with a sluice that separates the two lakes. In the past, periodical oscillations of the lake's level were in the range of one to three metres, depending on the amount of rain in the season. After the mid 80's, a steady decrease of the water level has been recorded that endanger the ecological balance of the lake and the watershed area resulting in serious consequences for the fishing and tourist industry in the trans-boundary Prespa region.

During the last two decades, a permanent decreasing of the water level of Prespa Lake has been recorded that drastically influences the ecological balance of the lake and the watershed area resulting in serious consequences for the fishing and tourist industry in the trans-boundary Prespa region. In addition to this, the industrial activities as well as the overuse of the herbicides in agriculture activities raised the problem of pollution of the water in the Prespa Lake. 
One of the major environmental issues today that may, as well, have serious security implications on the relation between the three neighbouring countries, is the question of global environmental degradation and increased shortages of renewable resources, especially international waters and water courses, joint river basins and joint lakes. Increased pressure on the environment and natural resources threatens the economic potentials of the countries and hence their internal political security. It is impossible to quantify the importance of this problem, since it involves the future of a natural resource of unique beauty, the future of the local communities and the stability of the Prespa Lake region.

The importance of Prespa Lake as an area of high ecological significance has been widely recognised by national Governments of the three countries sharing the Lake (several National Projects have been financially supported) and by international organizations and bodies (IAEA, NATO SPS, UNESCO) not only because of its natural beauty, but also because of its high biodiversity, including populations of rare water birds, like for example the Dalmatian pelican, a world vulnerable species, as well as for its cultural values including Byzantine monuments.

The willingness of the three governments to co-operate in order to promote the protection of all the Prespa area were established on the $2^{\text {nd }}$ February 2000, when the Prime Ministers of Albania, Greece and the FYRO Macedonia issued a trilateral declaration recognising the international importance of the Prespa Lakes as well as the need for co-operation in order to promote conservation of its natural and cultural values.

That is why, the fulfilment of various projects objectives (definition of the quality and quantity of the lake's water, lake water balance, hydrological relationship between the three lakes, volume determination of Prespa Lake's water and groundwater reservoir below Galichica Mountain), did make a significant contribution to the protection of the Ohrid-Prespa hydro-system and reinforces the peace and stability in the region.

\section{Methodology}

On the basis of the environmental isotopes $\left({ }^{3} \mathrm{H}, \delta^{2} \mathrm{H}\right.$ and $\left.\delta^{18} \mathrm{O}\right)$ distribution into the local hydrological cycle of the water within the Ohrid - Prespa Lake hydro system, it was expected the relationship between the Ohrid Prespa Lake to be established. A full evaluation of the data available in the previous years combined with the data collected for the project duration was used to estimate the implications on a complex system like the Prespa Lake is, where parameters like sinkholes, precipitation and evaporation, water inflow through rivers and streams and water used in agriculture have been taken into account.

The modelling part of the past activities included determination of:

- hydrological relationship between the Prespa and Ohrid lakes, as well as the mean residence time (MRT) of the infiltrated Prespa Lake waters through Galichica Mountain, by using environmental isotopes $\left({ }^{3} \mathrm{H}, \delta^{2} \mathrm{H}\right.$ and $\delta^{18} \mathrm{O}$ ) distribution into the local hydrological cycle of the water within the Ohrid - Prespa Lake hydro system and 
- Relationship between the Water level of the Prespa Lake and its surface, conducting to the evaluation of the Volume of the Prespa Lake, an important parameter for the study of the water pollution of the Prespa Lake. For this purpose, the results from the previously performed charting and profiling that have been obtained within the IAEA (International Atomic Energy Agency) funded project, were used.

The performed research advanced the scientific basis in this area, which will find its application in the future related research worldwide. For more detail for this approaches [2-9]

\subsection{Determination of environmental isotope distribution}

\subsubsection{Determination of $\delta^{2} \mathrm{H}$ and $\delta^{18} \mathrm{O}$}

After the physico-chemical pretreatment, using standard procedures for determination of $\delta^{18} \mathrm{O}$ ratio, an equilibrium of exchange between oxygen from commercial $\mathrm{CO}_{2}$ gas and water samples has been used, while for determination of $\delta^{2} \mathrm{H}$ ratio, reduction technique of water sample with $\mathrm{Zn}$-shots, mass spectrometric measurements have been applied, by using of WG Micromss $602 \mathrm{C}$.

\subsubsection{Determination of ${ }^{3} \mathrm{H}$ concentration in water samples}

Taking into account the relatively low concentrations of tritium in environmental water samples (precipitations, ground and surface waters), before their measurement on Beta-Liquid Scintillation Counter-Packard Instrument, M 3320, tritium concentrations have been enriched by using an electrolytic enrichment system.

\subsection{Artificial groundwater tracing}

In order to confirm the hydrological relationship between the Prespa Lake water that are draining through Galichica Mountain, towards the Ohrid Lake, recharging many springs, several recognition field trips within the Ohrid/Prespa Lake region as well as injection of an artificial tracer at Zaveri zone of sinkholes, have been performed.

\subsection{Determination the MRT by modelling of ground water}

Taking into the consideration the local geological conditions, relevant hydro meteorological and isotope data and by using an appropriate two components mixing model, shown in Fig. 2, supported by a computer program which implements an adequate recursive equation, the MRT of the infiltrated Prespa Lake waters through Galichica Mountain, that recharge the St. Naum and other Springs located on the South Eastern Coast line of the Ohrid Lake has been determined. 


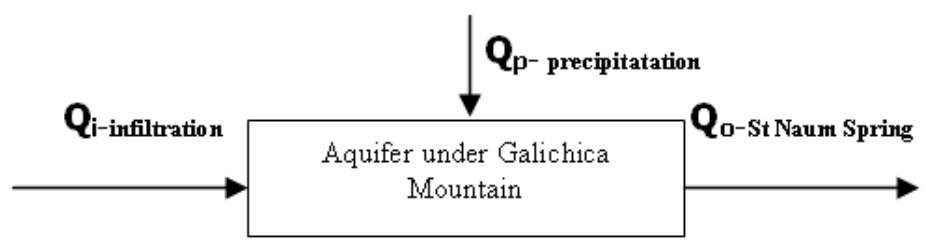

Figure 2: One cell model including mixing of two components (precipitation and infiltration of Prespa Lake waters).

\subsection{Determination the relationship between the volume and the water level of Prespa Lake}

In this sense, estimation of the surface of the lake corresponding to a certain range of depth [10-11] was of an essential issue in determination the relationship among the water level of the lake and its volume. Based on the results of these activities a computer program in $\mathrm{C}++$ language was created, offering a calculation of the volume of Prespa Lake by entering only the actual value of its water level.

\section{Results and discussion}

\subsection{Stable isotope distribution}

On the basis of the analysis of the stable environmental isotopes $\left(\delta^{2} \mathrm{H}\right.$ and $\left.\delta^{18} \mathrm{O}\right)$ distribution into the local hydrological cycle of the water within the Ohrid Prespa lakes hydro system, Figure 2, characteristics of the hydrological link between Prespa and Ohrid Lake have been analyzed.

As one of the main conclusions was that the Water in St. Naum and other surrounding Springs is mixture of these two components, with the following ratios:

- In the St. Naum Spring, $40 \%$ of the spring waters origins from Prespa Lake and $60 \%$ from precipitation.

- For Tushemiste Spring, the respective values of $55 \%$ and $45 \%$ were observed.

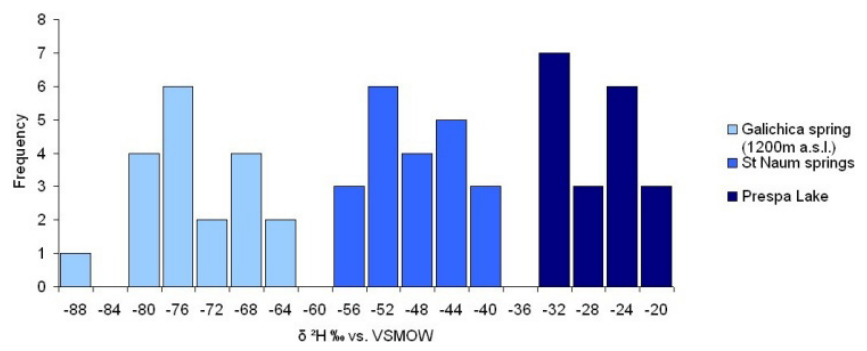

Figure 3: $\quad$ Frequency distribution of $\delta^{2} \mathrm{H}$ value in observed water samples. 
By analyzing the water balance in the hydrological system it was determined that $8.7 \mathrm{~m}^{3} / \mathrm{s}$ of the water in St. Naum, Tushemiste and other springs on the South-Eastern Coast of the Ohrid Lake are result of infiltration from the Prespa Lake.

\subsection{Artificial underground water tracing}

In order to determine the hydrological relationship between the sinkholes on the bed of the Prespa Lake that drain the water towards the Ohrid Lake, recharging many springs, injection of an artificial tracer (Na-Fluorescein) in Zaveri zone of sinkholes, has been performed in October 2007. Observation of the tracer in 13 springs, located on the south-eastern coast line of the Ohrid Lake has been performed by the end of 2008. The obtained so far results show that the appearance of the tracer has been relatively rapid. After few days its appearance on distances higher than $15 \mathrm{~km}$ has been registered. However, the registration of the earlier injected tracer (Sulphorhodamine G Extra), which took place in 2001, suggests existence of recharging components with an age of more than 5 years.

\subsection{Modeling of Tritium concentration distribution}

Taking into account the measured amount of precipitations and discharges of St. Naum and other springs of interest, enrichment of tritium content due to evaporation within Prespa Lake, as well as the above defined isotope ratios, it can be concluded that $8.7 \mathrm{~m}^{3} / \mathrm{s}$ of water is infiltrated through the Galichica Mountain into Ohrid Lake.

Apart from the above mentioned model, a computer code was developed in order to simulate the tritium concentrations into the water from St. Naum Spring. By solving the following recursive equation of Ref. [6], the output tritium concentration into the spring is simulated:

$$
S_{n}=\left(S_{n-1}+B R F * C B R F-B O F * C B O F\right) * \alpha
$$

where:
$S_{n} \quad$ is the simulated Tritium concentration in the St. Naum Spring Waters, for the current year of observation, (TU; in isotope hydrology when expressing the concentration of tritium in water samples, Tritium Units (TU) are used, $1 \mathrm{TU}={ }^{3} \mathrm{H} / 10^{18}$ $\left.{ }^{1} \mathrm{H}\right)$
$S_{n-1} \quad$ is the calculated Tritium concentration in the St. Naum Spring Waters, for the previous year of observation, (TU),
$B R F \quad$ is the Boundary Recharge Fraction (precipitation and ground water),


CBRF is the Concentration of the Boundary Recharge Fraction. This value comes from measured or estimated $\mathrm{TU}$ in the precipitation over Republic of Macedonia for the corresponding year of observation. When ground water is considered, this value is multiplied by the enrichment factor due to evaporation within Prespa Lake,

$B R F * C B R F$ is the product giving the boundary input mass within the cell, $B O F$ is the Boundary Outlet Fraction (precipitation and ground water), equals $B R F_{\text {precipitation }}+B R F_{\text {groundwater }}$,

$\mathrm{CBOF}$ is the Concentration Boundary Outlet Fraction, for the first year it is so, (TU),

$B O F * C B O F$ is the product that gives the boundary outlet mass leaving the cell,

$\alpha$

is the radioactive decay constant, where for one year is equal to 0.94

After comparing the results for the different MRT and concentration of enrichment, it has been confirmed that by taking into account 5 years for MRT and 1.3 for the enrichment factor due to the evaporation within Prespa Lake, the measured and the simulated results differ with minor acceptable deviations.

The determined MRT of the ground water with the value of 5 years has been also confirmed by recently performed tracer experiments by injection of artificial tracer in the Zaveri sinkhole in 2001 and its appearance in Tushemishte Spring, cca 6 years later i.e. in 2007 [5]. This is acceptable having in mind that in karstic area we are facing with many recharge components of various ages i.e. from hours to years.

The volume of the reservoir under the Galichica Mountain that recharge the St. Naum Spring has been determined to be of $3.1 \times 10^{9} \mathrm{~m}^{3}$ capacity.

\subsection{Modeling the relationship between the volume and water level of Prespa Lake}

As a result of the performed field work within the Ohrid-Prespa region, location of the most significant sinkholes on Prespa Lake, coastline and its bottom was determined. It seems that the locality of Zavir is one of the dominant locations where the water is sinking into the Galichica'a carstic masif, reaching latter a series of springs, located on the south-eastern coastline of Ohrid Lake.

\subsubsection{Assessment of the volume of the Prespa Lake water}

On the basis of performed depth profiling activities, the following differential surfaces, each corresponding to the certain depth range, have been estimated, see Table 1. 
Table 1: $\quad$ Estimated corresponding surface area as a function of the depth (for water level of the Lake $=844,58 \mathrm{~m}$ (asl).

\begin{tabular}{|c|c|}
\hline $\begin{array}{c}\text { Depth range } \\
(\mathbf{m})\end{array}$ & $\begin{array}{c}\text { Estimated corresponding } \\
\text { Surface area }\left(\mathbf{k m}^{\mathbf{2}}\right)\end{array}$ \\
\hline $0-10$ & 61,11 \\
\hline $10-20$ & 196,43 \\
\hline $20-30$ & 16,96 \\
\hline $30-50$ & 1,96 \\
\hline
\end{tabular}

The related partial volumes were calculated, the sum of which represents the total volume of the Lake, which equals $3,370 \times 10^{6} \mathrm{M}^{3}$.

Apart from the water level measurement and satellite Imagines of Prespa Lake, taken in the past, respective surface areas of Prespa Lake for measured water level are shown in Table 2.

Table 2: Estimated surfaces and corresponding measured water level of Prespa Lake

\begin{tabular}{|l|c|c|}
\hline $\begin{array}{c}\text { Big Prespa Lake } \\
\text { Dates of observation/sources }\end{array}$ & $\begin{array}{c}\text { Water level } \\
(\mathbf{m})(\mathbf{a s l} .)\end{array}$ & $\begin{array}{c}\text { Estimated Surface } \\
\left.\mathbf{( k m}^{\mathbf{2}}\right)\end{array}$ \\
\hline Summer 1978 / Landsat MSS & 848,56 & 276,00 \\
\hline Summer 1988/ Landsat TM & 848,39 & 273,70 \\
\hline Summer 2000/ Landsat ETM & 845,77 & 265,26 \\
\hline $\begin{array}{c}\text { Difference for the covered } \\
\text { period (1978-2000) }\end{array}$ & 3,54 & $\mathbf{1 0 , 7 4}$ \\
\hline
\end{tabular}


An exponential relationship, for the lake surface (y) as a function of depth (x), was obtained:

where:

$$
\mathrm{y}=\mathrm{ab}^{\mathrm{x}}
$$

Constant $-\mathrm{a}=0.00365059647$

Constant $-\mathrm{b}=1.01332072$

Correlation $(\mathrm{R})=0.9892194165$

The above equation enables one to determine the surface area of Prespa Lake for a certain water level, see Figure 4.

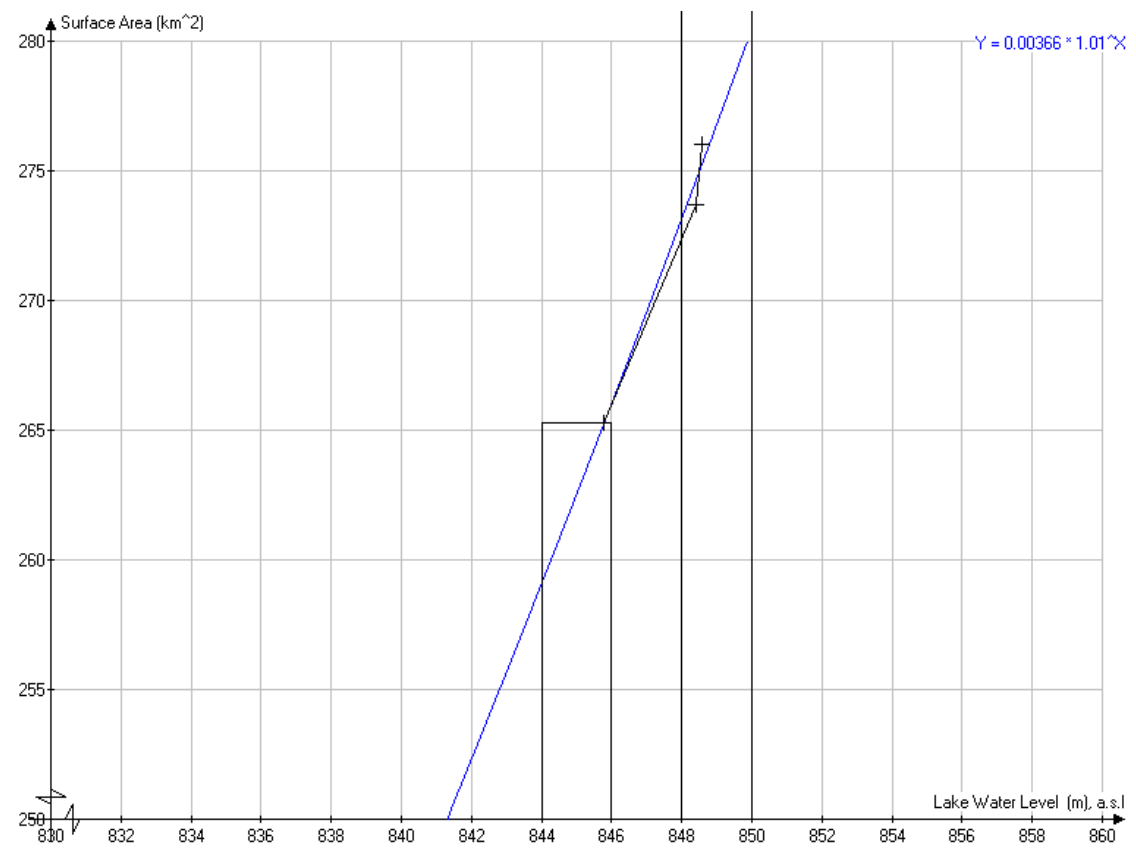

Figure 4: $\quad$ Prespa Lake surface as a function of depth.

Calculating the volume of Prespa Lake for certain referent level (for example: for water level of $847,68 \mathrm{~m}$ (asl.), calculated corresponding volume is $4,55 \times 10^{9} \mathrm{~m}^{3}$ ) and by using adequate computer program (made in $\mathrm{c}++$ program language), we are able to estimate the volume of the available Prespa Lake water. From the ecological point of view, this is an important parameter for further study of the capacity of the protected Prespa Lake ecosystem, knowing only its water level. For example: for water level of Prespa Lake equal to: $850.68 \mathrm{~m}$ (asl.), the following parameters are calculating by the applied computer program:

- Corresponding Surface Area of Prespa Lake is: $2.830 \times 10^{8} \mathrm{~m}^{2}$

- Corresponding Volume of water of Prespa Lake is: $5,38 \times 10^{9} \mathrm{~m}^{3}$ 
- Prespa Lake water level difference comparing to the referent level of 847. $68 \mathrm{~m}$ (asl.) is: $\Delta \mathrm{h}=3 \mathrm{~m}$

- $\quad$ Prespa Lake's surface area difference related to the referent level is: 1,1 $\mathrm{x} 10^{7} \mathrm{~m}^{2}$

- Prespa Lake's water volume difference related to the referent level is: $8.3 \times 10^{8} \mathrm{~m}^{3}$.

\section{Conclusion}

On the basis of the performed study of the Prespa/Ohrid hydro system, the following conclusions could be drawn:

- Close cooperation, starting in 1997 up to present, among various research teams in the neighbouring countries sharing the waters from Prespa and Ohrid Lakes, shows to be a very efficient way of conducting complementary projects in the Region

- Environmental isotopes distribution within the hydrological cycle of the water could be used as an effective hydrological tool, especially in the region where isotope fractionations can occur, i.e. involving of surface water accumulations or else.

- Although the tritium content into the precipitation is approaching the natural level 4-6 TU it still can be used as an efficient tool in hydrological investigations and particularly, for the observed hydro systems where historical tritium data are available.

- As a MRT for the water reaching the underground reservoir and supplying the St. Naum and other springs located at the south-eastern coast of Ohrid Lake a value of MRT $=5$ years has been calculated and confirmed by artificial tracer experiments.

- Taking into account the value of the MRT $=5$ years and other relevant hydrological parameters and isotope data (spring discharge, participation of Prespa Lake water into the water of the observed springs), for the volume of the groundwater reservoir (under the Galichica Mountain) a value of cca $3.1 \times 10^{9} \mathrm{~m} 3$ has been estimated.

- Applied methodology for calculating the volume of Prespa Lake water has been shown as an efficient tool for sustainable management of the international Prespa Lake waters.

\section{Acknowledgements}

This work is supported by: IAEA REG Project RER 8/008, UNESCO (Project No. 37542103 MCD) and The NATO Science for Peace and Security programme (Project No. SfP 981116); 


\section{References}

[1] CVIJIC, J., Fundamentals of Geography and Geology of Macedonia and Serbia, Special Edition VIII+680, Belgrade (1906).

[2] ANOVSKI, T., et al., A study of the origin of water in the St. Naum's Springs, Lake Ohrid, FIZIKA - A J. of Exp. and Theoretical Physics, Vol. 12 (S2), (1980).

[3] EFTIMI,R., ZOTO, J., Isotope study of the connection of Ohrid and Prespa lakes, Proceed. Of the International Symposium "Towards Itergrated Conservation and Sustainable Development of Transboundry Macro and Micro Prespa Lakes", Korcha, Albania (1997) 32-37.

[4] LEONTIADIS, I.L., STAMOS, A., Isotopiki hydrologiki erevna evryteris periochis ano rou Aliakmona, 5th panhellenic hydrog. symposium, Limasol, Cyprus (1999).

[5] FINAL REPORT ON NATO PROJECT - SPS No. 981116, Sustainable Management of the International Waters - Prespa Lake, Group of authors (2010).

[6] SIMPSON, E.S., Application of the multi-cell mixing models to the interpretation of the environmental isotope data, IAEA Internal Report (1972).

[7] Anovska-Jovcheva, E., Jovchev, Z., Anovski, T., Popov, V., ’Determining MRT of Ground Water by Application of the Distribution of Environmental (Hydrogen and Oxygen) Isotopes", IAEA, CN-186,Monaco, 2011.

[8] Anovska-Jovcheva, E., Jovchev, Z., Anovski, K., Stojmenovska, I., Milevski, J., Popov, V., Anovski, T., "Study on the Relationship between the Water level of the Prespa Lake", Natura Montegrina, Montenegro, 2008

[9] Anovski, T., Eftimi, R., Leontijadis, I., Stamos, A., Beska, P., Andrinopoulos, A., Amataj, S., "Progress in Study of Prespa Lake by Application of Nuclear and Related Technicues", Monography edited by Prof. T.Anovski, Faculty of Tecnology and Metallurgy, Univ. Sts Kyril and Methodius, Skopje, R of Macedonia, 2001.

[10] A. Andrinopoulos, IGME, Athen's, Greece (personal communication).

[11] E. Charou and M. Stefouli, ESA 2nd Space for hydrology Workshop Geneva, Switzerland, November 2007 (in press). 